УДК $351: 328.18]$

https://doi.org/10.52058/2786-5274-2022-1(3)-35-45

Омельченко Роман Петрович студент магістратури кафедри глобальної та національно безпеки ННІ Публічного управління та державної служби, КНУ імені Тараса Шевченка, вул. Антона Цедіка, 20, м. Київ, 03057, тел.: (097) 138-97-55, https://orcid.org/0000-0002-5833-4359

\title{
ПРОБЛЕМИ ФОРМУВАННЯ НАЦІОНАЛЬНОЇ СТІЙКОСТІ НА РІВНІ РЕГІОНІВ І МІСЦЕВИХ ГРОМАД В УКРАЇНI
}

Анотація. У статті обгрунтовано необхідність формування та реалізації державної політики розбудови національної стійкості як складової забезпечення національної безпеки України в умовах гібридної війни. Запропоновано напрями удосконалення державної політики формування національної стійкості як складової забезпечення національної безпеки України в сучасних умовах відсічі і стримування збройної агресії Російської Федерації на Сході України

Проаналізовано проблеми формування національної стійкості на рівні регіонів і місцевих громад в Україні та шляхи їх вирішення.

У статті наголошується що для вирішення проблемних питань під час формування комплексної організаційної моделі забезпечення стійкості регіонів і територіальних громад, доцільно зосередити основні зусилля відповідних органів державної влади та місцевого самоврядування на таких аспектах: врегулюванні питання термінологічної визначеності понять у сфері розбудови національної стійкості; унормування порядку дій суб'єктів забезпечення національної стійкості; формування стратегічних і програмних документів у сфері забезпечення безпеки та стійкості регіонів і територіальних громад 3 чітким визначених цілей i завдань; визначенні обласних державних адміністрацій головними координаторами у процесі формування стійкості регіонів, а органів місцевого самоврядування та їх виконавчих органів - на рівні територіальних громад; розширенні повноваження обласних державних адміністрацій в частині, що стосується міжвідомчої співпраці, забезпечення процесу комплексного оцінювання ризиків і виявлення загроз, ведення регіонального реєстру загроз, утворення профільних міжвідомчих робочих груп тощо.

Робиться висновок проте, що враховуючи потребу в розбудові багаторівневої комплексної системи забезпечення національної стійкості, механізми міжвідомчої взаємодії та координації діяльності у сфері національної безпеки на регіональному i місцевому рівнях потребують вдосконалення. Це сприятиме забезпеченню безперервності процесів 
управління та надання критично важливих послуг населенню, як в умовах мирного часу, так і під час кризової ситуації, протягом повного циклу забезпечення національної стійкості.

Ключові слова: національна стійкість, національна безпека, державна політика, регіони, місцеві громади.

Omelchenko Roman Petrovich Master's student of the Departments of Global and National Security, Institute of Public Administration and Civil Service of Taras Shevchenko National University, Anton Tsedik St., 20, Kyiv, 03057, tel.: (097) 138-97-55, https://orcid.org/0000-0002-5833-4359

\section{PROBLEMS OF FORMATION OF NATIONAL RESISTANCE AT THE LEVEL OF REGIONS AND LOCAL COMMUNITIES IN UKRAINE}

Abstract. The article substantiates the need for the formation and implementation of state policy of building national stability as a component of ensuring the national security of Ukraine in a hybrid war. The directions of improvement of the state policy of formation of national stability as a component of maintenance of national security of Ukraine in modern conditions of repulse and deterrence of armed aggression of the Russian Federation in the East of Ukraine are offered.

The problems of formation of national stability at the level of regions and local communities in Ukraine and ways of their solution are analyzed.

The article emphasizes that to solve problems during the formation of a comprehensive organizational model for ensuring the stability of regions and territorial communities, it is advisable to focus the main efforts of relevant public authorities and local governments on the following aspects: regulation of the order of actions of subjects of ensuring national stability; formation of strategic and program documents in the field of security and sustainability of regions and territorial communities with clearly defined goals and objectives; determination of regional state administrations as the main coordinators in the process of forming the stability of regions, and local self-government bodies and their executive bodies - at the level of territorial communities; expanding the powers of regional state administrations in the part related to interdepartmental cooperation, ensuring the process of integrated risk assessment and threat detection, maintaining a regional register of threats, establishing specialized interdepartmental working groups, etc.

It is concluded, however, that given the need to build a multilevel integrated system of national stability, the mechanisms of interagency cooperation and coordination of activities in the field of national security at the regional and local levels need to be improved. This will help ensure the continuity of governance processes and the provision of critical services to the population, both in peacetime and in times of crisis, throughout the cycle of national stability. 
Keywords: national resilience, national security, public policy, regions, local communities.

Постановка проблеми. Дослідження проблем формування національної стійкості в контексті забезпечення національної безпеки України в цілому та на регіональному рівні зокрема є недостатніми для сьогоднішнього рівня викликів та загроз, що постають перед Україною. Сучасний світ характеризується непередбачуваністю i мінливістю безпекового середовища, змінами в архітектурі світової, регіональної та національної безпеки, зростанням рівня загроз та їх потенційних наслідків в умовах екзистенційної воєнної загрози національній безпеці України з боку Російської Федерації, іiї постійних спроб дестабілізувати безпекове середовище в Чорноморському регіоні, проведення «газової війни» та створення штучної міграційної кризи на кордонах 3 Свропейським Союзом, як сегменту гібридної війни в Свропі, світовою пандемією та регіональними конфліктами. Все це формує довгострокові виклики для України і одночасно вносить в порядок денний забезпечення національної безпеки, як невідкладне, питання розбудови національної стійкості.

Руйнівні наслідки надзвичайних ситуацій, як результат глобальних змін клімату, світове протистояння окремих держав і військово-політичних блоків, пандемія планетарного масштабу, що спричинена поширенням коронавірусної хвороби (COVID-19), суттєво позначилися на міжнародній безпеці, продемонстрували слабкість, а інколи й дисфункцію, наявних політичних інструментів й інститутів, які забезпечували мир i стабільність. В умовах стрімких змін безпекового середовища, класичних підходів щодо реагування на загрози виявилося недостатньо для того, щоб люди, громади, суспільство i держава були достатньо захищеними. Актуалізовано питання щодо набуття системою забезпечення національної безпеки нової якості, з метою адаптації до таких змін і безперервної роботи навіть в умовах кризи.

Зазначеним вимогам відповідає концепт «національної стійкості». Разом 3 тим, неоднозначне тлумачення і часом контраверсійне розуміння поняття «національна стійкість», різні підходи до визначення складових національної

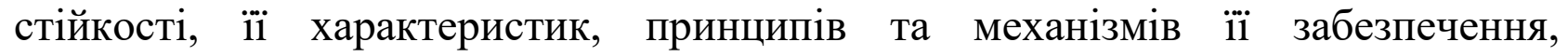
потребують вивчення та узагальнення існуючих тенденцій та кращих світових практик щодо забезпечення національної стійкості 3 метою їх уніфікації та опрацювання концепції і дорожньої карти щодо їх впровадження в Україні 3 урахуванням національних особливостей.

Актуальність проблематики формування та реалізації державної політики щодо забезпечення національної стійкості також зумовлюється тим, що в Україні питання запровадження національної системи стійкості знаходиться на стадії розвитку та організаційно-правової інституціоналізації. Елементи даної системи не завжди є пов'язаними між собою, функції суб'єктів забезпечення 
національної стійкості не розмежовані і часто дублюються, що впливає на ефективність їх діяльності. Для завчасної підготовки, адекватного реагування на виклики і загрози, національній безпеці потрібні комплексні узгоджені дії всіх ключових суб'єктів національної системи стійкості.

Визначення стійкості однією із засад Стратегії національної безпеки, що введена у дію Указом Президента України від 14 вересня 2020 року № 392/2020, а також нормативно закріплені наміри щодо запровадження національної системи стійкості для забезпечення високого рівня готовності суспільства і держави до реагування на широкий спектр загроз [2], стали новим етапом у розробці концептуальних основ та підготовки збалансованих пропозицій для формування та реалізації державної політики щодо забезпечення національної стійкості.

Аналіз останніх досліджень і публікацій. У процесі підготовки кваліфікаційної роботи були використані фундаментальні праці науковців із різних аспектів державного управління національною безпекою. Так, вивченню концепту «стійкості», «національної стійкості» та питань формування державної політики забезпечення національної стійкості присвячені роботи українських і зарубіжних вчених, які проводили дослідження в трьох основних напрямках: теоретико-методологічному (Ф. Бурбо, Н. Мартін, Дж. Джозеф, Л. Алессі, К. Зебровскі, П. Бенцзур, Б. Еванс,), нормативно-правовому (А. Р. Манка, С. П. Іванюта, К. С. Войтовський, Е. Жіованіні) та структурнофункціональному (Д. Г. Бобро, А. В. Лепіхов, А. Мітчел, Ф. Камполонго).

Вивченню практично всіх аспектів національної стійкості та виробленню рекомендацій щодо їх впровадження в державно-управлінську діяльність в Україні присвячено роботи О.О. Резнікової.

Науковцями достатньо вивчено також окремі аспекти та сфери національної стійкості, зокрема питання стійкості критичної інфраструктури (О. М. Суходоля), економічної стійкості (А. В. Бойко), інформаційної стійкості (Р. Р. Марутян), екологічної стійкості (І. С. Варламова), фінансової стійкості (Н. В. Нестеренко).

Праці згаданих дослідників створили методологічне підгрунтя для комплексного розгляду переважної більшості проблем у сфері формування i реалізації державної політики забезпечення національної стійкості. Ретроспективний аналіз даного питання дозволяє зробити висновок, що у сучасній літературі недостатньо дослідженими залишаються проблеми формування національної стійкості на рівні регіонів і місцевих громад в Україні.

Крім того, значна увага питанням розвитку стійкості приділяється міжнародними інституціями. Грунтовні дослідження стійкості проводяться відповідними підрозділами Організації Об’єднаних Націй, Організації Північноатлантичного Договору, Європейського Союзу, Організації економічного співробітництва та розвитку та інших. Питання розвитку 
стійкості інкорпоровано у стратегічні документи згаданих організацій i гармонізовано з розвитком ключових пріоритетів їх діяльності.

Мета статті. Автор статті ставить за мету дослідити проблеми формування національної стійкості на рівні регіонів і місцевих громад в Україні та шляхи їх вирішення.

Виклад основного матеріалу. Більшість провідних країн світу визначили формування національної стійкості імперативом формування своєї безпекової політики. Стійкість також визначається пріоритетним напрямком формування політики в оновлених стратегічних документах Свропейського Союзу та Організації Північноатлантичного Договору. Разом 3 тим, у світі відсутнє загальноприйняте визначення цього поняття, не сформульовані чіткі механізми та критерії формування відповідної системи.

Як у багатих, так і в бідних країнах зростає політичне та економічне тяжіння до підвищення стійкості як порядку денного, який може сприяти цілісним, позитивним i тривалим змінам у суспільствах і країнах, яким найбільше загрожує небезпека. Порядок денний зазвичай розуміється як інституційний підхід, який узгоджує різні дії з управління ризиками, що охоплюють як техногенні загрози, так і природні небезпеки, а також різні форми надання допомоги, що охоплюють як короткочасні (наприклад, повені) так і довготривалі катастрофи (наприклад, посуха), а також складні надзвичайні ситуації (наприклад, довготривалий конфлікт) [7].

Інтерес до стійкості стрімко зростав протягом останніх 20 років, як відповідь на зростаюче занепокоєння з приводу потенційних потрясінь, які перевіряють межі спроможності людей і суспільства їх подолати. Цілком імовірно, що ці потрясіння залишилися назавжди і будуть створювати постійні виклики в усьому світі, від цифрової трансформації, глобалізації та демографії до зміни клімату та продовольчої безпеки. Щоб успішно боротися 3 цими проблемами, важливо розуміти, що робить суспільство здатним впоратися 3 потрясіннями, а також постійно вимірювати та контролювати свої можливості щодо їх подолання [6].

Ураховуючи зміни, що відбуваються сьогодні як у глобальному безпековому середовищі, так і в системі суспільних відносин, особливої актуальності серед досліджень набувають питання формування та реалізації державної політики національної стійкості, у тому числі стійкості окремих іiі суб'єктів - державних органів, суспільства, організацій.

Зокрема, наголошується на необхідності зміни формату взаємодії у сфері забезпечення національної безпеки, розвитку спроможностей залучених суб’єктів, а також вдосконаленні механізмів реагування на загрози.

Водночас потрібно враховувати, що рекомендації, які надаються окремими експертами у сфері розбудови національної стійкості, іноді мають різновекторний і фрагментарний характер, а відповідні моделі і підходи, які засвідчили ефективність в інших державах, мають бути адаптованими до 
національних особливостей.

Останнім часом все більше уваги приділяється розвитку національної стійкості на регіональному та місцевому рівнях як окремими дослідниками, так і міжнародними організаціями та науково-дослідними установами.

Ще навіть до прийняття Стратегії національної безпеки України та Концепції забезпечення НСС постановою Кабінету Міністрів України від 5 серпня 2020 р. № 695 «Про затвердження Державної стратегії регіонального розвитку на 2021-2027 роки» серед основних завдань за напрямком розвитку інфраструктури безпеки у рамках оперативної цілі 4 стратегічної цілі 1 визначено побудову Національної системи стійкості на регіональному рівні [1].

Концепцією забезпечення НСС визначено завдання щодо організації та функціонування національної системи стійкості на державному, регіональному та місцевому рівнях [5].

Ураховуючи те, що концептуальні документи 3 питань забезпечення національної стійкості затверджено нещодавно, законодавство, яке б визначало завдання, функції і повноваження як органів державної влади, так і органів місцевого самоврядування у сфері забезпечення національної стійкості на сьогодні не сформовано.

Оскільки одним 3 ключових принципів забезпечення національної стійкості є принцип субсидіарності, що передбачає розподіл повноважень i відповідальності, коли рішення щодо реагування на кризові ситуації приймаються на найнижчому рівні 3 координацією на вищому доцільному рівні, важливе значення має розбудова спроможностей регіонів i територіальних громад з питань забезпечення національної стійкості.

Реагування на загрози і надзвичайні ситуації, забезпечення готовності, ліквідація наслідків надзвичайних ситуацій та відновлення після них на регіональному i місцевому рівнях сьогодні відбувається в рамках законодавства у сфері національної безпеки, а також на основі відповідних відомчих нормативно-правових актів.

Як відзначають експерти Національного інституту стратегічних досліджень, сьогодні на рівні регіонів i місцевих громад «комплексне реагування на певні види загроз відбувається в межах функціонування окремо діючих загальнодержавних систем: єдиної державної системи цивільного захисту України; єдиної державної системи запобігання, реагування i припинення терористичних актів та мінімізації їх наслідків (загальнодержавної системи боротьби 3 тероризмом); системи екстреної медичної допомоги; національної системи кібербезпеки України; системи забезпечення обороноздатності держави. Їх організаційні і нормативно-правові механізми охоплюють усю територію країни, а деякі із систем складаються 3 функціональних і територіальних підсистем» [4].

Спектр діяльності цих систем націлено на захист населення від надзвичайних і кризових ситуацій природного, техногенного, соціального, 
терористичного, воєнного та іншого характеру; гарантування сталої роботи систем життєзабезпечення територіальних громад (постачання енергоресурсів, продовольства, питної води, забезпечення охорони здоров'я і невідкладної медичної допомоги, громадської безпеки, транспортних комунікацій, житловокомунальної інфраструктури); охорону та оборону об'єктів підвищеної небезпеки, що розміщені на територіях регіонів і територіальних громад.

У рамках чинного законодавства у сфері запобігання і реагування на загрози та надзвичайні ситуації на регіональному і місцевому рівнях як на постійній, так і на тимчасовій основі утворюються такі основні органи міжвідомчої взаємодії: координаційні групи Антитерористичного центру при регіональних органах СБУ, регіональні й місцеві комісії з питань техногенноекологічної безпеки та надзвичайних ситуацій, спеціальні комісії з ліквідації наслідків надзвичайної ситуації, комісії 3 питань надзвичайних ситуацій підприємств, установ та організацій, а також центри безпеки громадян.

Сьогодні основні функції щодо реагування на кризові ситуації та забезпечення готовності на регіональному і місцевому рівнях покладено на обласні і районні державні адміністрації, органи самоврядування об'єднаних територіальних громад, регіональні і територіальні підрозділи сил безпеки i оборони, служби невідкладної медичної допомоги.

На перший погляд, складається враження, що на регіональному i місцевому рівнях створено всі необхідні умови щодо забезпечення національної стійкості.

Разом 3 тим групою експертів Національного інституту стратегічних досліджень визначено ряд проблем у сфері формування стійкості регіонів i територіальних громад, які умовно можна розділити на чотири групи:

законодавчого та нормативно-правового характеру:

- недосконалість правового регулювання процесу впровадження єдиного системного механізму координації діяльності в рамках повного циклу забезпечення національної стійкості (оцінювання ризиків, виявлення вразливостей, забезпечення готовності, планування, запобігання, реагування, посткризове відновлення);

- розпорошеність правового регулювання процесів забезпечення готовності й реагування на певні загрози і надзвичайні ситуації в різних законодавчих та нормативно-правових актах України, а також часткова неузгодженість між собою визначених в цих документах термінів, організаційних механізмів та методичних підходів;

проблеми у сфері стратегічного планування:

- відсутність в системі стратегічного планування в Україні чітких механізмів узгодження всіх процесів підготовки стратегічних і програмних документів на національному, регіональному i місцевому рівнях у рамках єдиного циклу; 
- відсутність стратегічного бачення розвитку безпекового середовища на регіональному і місцевому рівнях;

- незавершеність реформ щодо децентралізації влади;

інституційного характеру:

- не визначено чітких зв'язків між функціонуванням існуючих національних систем 3 реагування на певні види загроз і небезпек, які передбачають міжвідомчу взаємодію;

- утворені в рамках загальнодержавних систем різноманітні формати міжвідомчої співпраці (координаційні органи та міжвідомчі групи) функціонують у вузькому полі розрізнених сфер відповідальності;

комунікаційного характеру:

- не налагоджено комплексний обмін інформацією про всі можливі загрози й надзвичайні ситуації;

- не набули поширення сучасні методи й технології оцінювання ризиків і загроз;

- низький рівень розвитку державно-приватного партнерства у безпековій сфері на територіальному рівні;

- недостатньо використовується потенціал існуючих міжвідомчих структур як платформ для горизонтальної $\mathrm{i}$ вертикальної міжвідомчої взаємодії, комунікацій бізнесу та громадських організацій 3 органами самоврядування [3, С. 96-108].

3 метою вирішення проблемних питань під час формування комплексної організаційної моделі забезпечення стійкості регіонів і територіальних громад, доцільно зосередити основні зусилля відповідних органів державної влади та місцевого самоврядування на таких аспектах:

при вирішенні проблем законодавчого та нормативно-правового характеру:

- врегулювання питання термінологічної визначеності понять у сфері розбудови національної стійкості як на державному, так і на регіональному i місцевому рівнях;

- унормування порядку дій суб'єктів забезпечення національної стійкості під час імплементації повного циклу забезпечення національної стійкості (оцінювання ризиків, виявлення вразливостей, планування дій, забезпечення готовності, реагування, пом'якшення негативного впливу, ліквідація наслідків, посткризове відновлення/адаптація, вивчення отриманого досвіду);

при вирішенні проблем у сфері стратегічного планування:

- формування стратегічних і програмних документів у сфері забезпечення безпеки та стійкості регіонів і територіальних громад 3 чітким визначених цілей і завдань;

- періодичне проведення оцінювання прогресу реалізації визначених цілей і завдань $з$ урахуванням встановлених критеріїв та очікуваних результатів; при вирішенні проблем інституційного характеру: 
визначення обласних державних координаторами у процесі формування стійкості регіонів, а органів місцевого самоврядування та їх виконавчих органів - на рівні територіальних громад;

- розширити повноваження обласних державних адміністрацій в частині, що стосується міжвідомчої співпраці, забезпечення процесу комплексного оцінювання ризиків і виявлення загроз, ведення регіонального реєстру загроз, утворення профільних міжвідомчих робочих груп;

- визначення чіткого механізму взаємодії обласних державних адміністрацій з Кабінетом Міністрів України, Радою національної безпеки $\mathrm{i}$ оборони України та відповідними державними органами з питань забезпечення безпеки та стійкості;

- розширення функцій, завдань місцевих комісій 3 питань техногенноекологічної безпеки та надзвичайних ситуацій в частині забезпечення безпеки та стійкості регіонів і територіальних громад;

- утворення мережі допоміжних органів для вирішення спільних питань забезпечення безпеки та стійкості регіонів і територіальних громад;

- формування спільних організаційних, безпекових та інших спроможностей регіонів і громад, що необхідні для забезпечення їх стійкості;

- реалізація реформ, пов'язаних з децентралізацією влади в України, що сприятиме формуванню спроможностей системи забезпечення національної безпеки щодо ефективного первинного реагування;

комунікаційного характеру:

- побудова системи обміну інформацією між державними органами та органами місцевого самоврядування про можливі загрози й надзвичайні ситуації;

- впровадження сучасних методів й технологій оцінювання ризиків i загроз, опрацювання регіонального реєстру ризиків;

- удосконалення системи оповіщення населення регіонів і громад про можливі загрози й надзвичайні ситуації;

- забезпечення розвитку форматів державно-приватного партнерства у безпековій сфері на рівні регіонів і територіальних громад.

Важливе значення у розбудові національної стійкості на регіональному та місцевому рівнях має вивчення, узагальнення та впровадження прогресивного міжнародного досвіду у цій сфері.

Висновки. Розбудовуючи в Україні систему національної стійкості, важливо враховувати наявні спроможності та механізми, і не руйнуючи їх, розвивати та за потреби доповнювати новими. Необхідно також провести юридичний аудит чинного законодавства з метою уточнення й удосконалення його норм.

Підсумовуючи викладене, слід зазначити, що сьогодні в Україні створено механізми міжвідомчої взаємодії під час дії правових режимів надзвичайного $і$ воєнного стану, у ході реагування на надзвичайні ситуації та виконання 
завдань з протидії тероризму. Особливості організації та забезпечення такої діяльності на територіальному рівні визначено законодавством.

Разом $з$ тим, ураховуючи потребу в розбудові багаторівневої комплексної системи забезпечення національної стійкості, механізми міжвідомчої взаємодії та координації діяльності у сфері національної безпеки на регіональному i місцевому рівнях потребують вдосконалення. У першу чергу, це сприятиме забезпеченню безперервності процесів управління та надання критично важливих послуг населенню, як в умовах мирного часу, так і під час кризової ситуації, протягом повного циклу забезпечення національної стійкості.

Перспективи подальших розвідок у даному напрямі автор бачить у розробці пріоритетних напрямів вдосконалення державної політики формування національної стійкості України.

\section{Лimepamypa:}

1. Про затвердження Державної стратегії регіонального розвитку на 2021-2027 роки. Постанова Кабінету Міністрів України від 5 серпня 2020 p. № 695 . URL: https://zakon.rada.gov.ua/laws/show/695-2020-\%D0\%BF\#Text.

2. Про рішення Ради національної безпеки і оборони України від 14 вересня 2020 року «Про Стратегію національної безпеки України». Указ Президента України №392/2020 від 14 вересня 2020 року. URL: https://zakon.rada.gov.ua/laws/show/392/2020\#Text.

3. Резнікова О. О., Войтовський К. Є. Лепіхов А. В. Організація системи забезпечення національної стійкості на регіональному і місцевому рівнях. Аналітична доповідь. Національний інститут стратегічних досліджень. - К. : НІСД, 2021. - 140 с.

4. Резнікова О. О., Войтовський К. Є. Лепіхов А. В. Щодо координації діяльності 3 розбудови національної стійкості (стратегічний рівень). Аналітична записка. Національний інститут стратегічних досліджень. К. : НІСД, 2020. 14 с.

5. Указ Президента України від 27 вересня 2021 року № 479/2021 «Про рішення Ради національної безпеки і оборони України від 20 серпня 2021 року «Про запровадження національної системи стійкості»»». URL: https://zakon.rada.gov.ua/laws/show/479/2021\#Text.

6. Alessi, L., Benczur, P., Campolongo, F. et al. The Resilience of EU Member States to the Financial and Economic Crisis. Soc Indic Res 148, 569-598 (2020). URL: https://link.springer.com/content/pdf/10.1007/s11205-019-02200-1.pdf.

7. Mitchell A. Risk and Resilience: From Good Idea to Good Practice. A scoping study for the Experts Group on Risk and Resilience. URL: https://www.oecd-ilibrary.org/docserver/ $5 \mathrm{k} 3 \mathrm{ttg} 4 \mathrm{cxcbpen}$. pdf? expires $=1635184197 \& \mathrm{id}=\mathrm{id} \&$ accname$=$ guest $\&$ checksum $=457 \mathrm{~B} 65634 \mathrm{EDEF} 4$ 0C08D0DB1D0C179D4F.

\section{References}

1. Postanova Kabinetu Ministriv Ukraïni "Pro zatverdzhennja Derzhavnoï strategiï regional'nogo rozvitku na 2021-2027 roki" [The Resolution of the Cabinet of Ministers of Ukraine "On approval of the State Strategy for Regional Development for 2021-2027 "]. (n.d.). zakon.rada.gov.ua. Retrieved from https://zakon.rada.gov.ua/laws/show/695-2020-\%D0\%BF\#Text [in Ukrainian].

2. Ukaz Prezidenta Ukraïni "Pro rishennja Radi nacional'noï bezpeki i oboroni Ukraïni vid 14 veresnja 2020 roku «Pro Strategiju nacional'noï bezpeki Ukraïni»" [The Decree of the President of Ukraine "On the decision of the National Security and Defense Council of Ukraine of September 14, 2020 "On the National Security Strategy of Ukraine"'’]. (n.d.). zakon.rada.gov.ua. Retrieved from https://zakon.rada.gov.ua/laws/show/392/2020\#Text [in Ukrainian]. 
3. Reznikova, O. O., Vojtovs'kij, K. C. Lepihov, A. V. (2021). Organizacija sistemi zabezpechennja nacional'noï stijkosti na regional'nomu i miscevomu rivnjah [Organization of the system of national stability at the regional and local levels]. K. : NISD [in Ukrainian].

4. Reznikova, O. O., Vojtovs'kij, K. C. Lepihov, A. V. (2020). Shhodo koordinaciï dijal'nosti $z$ rozbudovi nacional'noï stijkosti (strategichnij riven') [On the coordination of activities to build national stability (strategic level)]. K. : NISD [in Ukrainian].

5. Ukaz Prezidenta Ukraïni «Pro rishennja Radi nacional'noï bezpeki i oboroni Ukraïni vid 20 serpnja 2021 roku «Pro zaprovadzhennja nacional'noï sistemi stijkosti»»» [The Decree of the President of Ukraine "On the decision of the National Security and Defense Council of Ukraine of August 20, 2021" On the introduction of the national system of stability"] (n.d.). zakon.rada.gov.ua. Retrieved from https://zakon.rada.gov.ua/laws/show/479/2021\#Text [in Ukrainian].

6. Alessi, L., Benczur, P., Campolongo, F. et al. The Resilience of EU Member States to the Financial and Economic Crisis. Soc Indic Res 148, 569-598 (2020). URL: https://link.springer.com/content/pdf/10.1007/s11205-019-02200-1.pdf.

7. Mitchell A. Risk and Resilience: From Good Idea to Good Practice. A scoping study for the Experts Group on Risk and Resilience. URL: https://www.oecd-ilibrary.org/docserver/ $5 \mathrm{k} 3 \mathrm{ttg} 4 \mathrm{cxcbpen}$. pdf?expires $=1635184197 \& \mathrm{id}=\mathrm{id} \&$ accname $=$ guest $\&$ checksum $=457 \mathrm{~B} 65634 \mathrm{EDEF} 4$ 0C08D0DB1D0C179D4F. 